\title{
Masculinization in common carp (Cyprinus carpio) by androgen immersion: The interaction effect of hormone concentration and immersion time
}

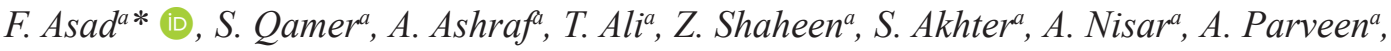 \\ N. Cheema a and G. Mustafa ${ }^{a}$

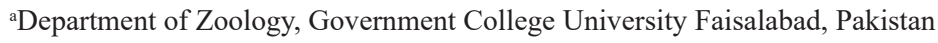 \\ *e-mail: far_khane@yahoo.com
}

Received: May 30, 2019 - Accepted: November 22, 2019 - Distributed: May 31, 2021

(With 2 figures)

\begin{abstract}
Synthetic androgens (male hormones) administered to fish nursery are being used in aquaculture to avoid sexual differentiation and unwanted spawning at the eggs or the first feeding fry stage of fish. Present trial was conducted with the aim to produce male common carp (Cyprinus carpio) by egg immersion technique. Through this little insight, the effect of different hormone concentrations (17 $\alpha$-methyltestosterone @ HC:150, 300, 450 and $600 \mu \mathrm{gl}^{-1}$ ) with immersion times (IT: 24, 48 and $72 \mathrm{hrs)} \mathrm{and} \mathrm{their} \mathrm{interaction} \mathrm{effect} \mathrm{(HC} \mathrm{x} \mathrm{IT)} \mathrm{on} \mathrm{the} \mathrm{hatching} \mathrm{percentage} \mathrm{of} \mathrm{Cyprinus} \mathrm{carpio}$ eggs, percent survival and percent of male's production was evaluated specifically. Results showed that egg hatching percentage decreased with increased IT likewise, survival of treated fry was affected by increasing the IT $(\mathrm{P}<0.001)$. The main interaction effect of HC x IT showed that the highest percent of male individuals (95\%) was obtained at 450-600 $\mu \mathrm{gl}^{-1} \mathrm{HC}$ for $72 \mathrm{hrs}$ IT, followed by $88-92.50 \%$ at $150-300 \mu \mathrm{gl}^{-1} \mathrm{HC}$ for 72 -hrsof IT, $87.50 \%$ at 48 -hrs of IT for rest of the hormone treatments, and lowest $47.50 \%$ was recorded in control $(\mathrm{P}<0.05)$. Increased percent male of Cyprinus carpio was obtained with increasing HC across all ITs. It was observed that the immersion treatment at $600 \mathrm{\mu gl}^{-1}$ for 72 hours was more effective to change the sex ratio of pre hatch Cyprinus carpio. A comparative outlook made from this experimental trial that sex induction of Cyprinus carpio by eggs immersion using synthetic male steroid hormone is an alternative safe technique of fish sex reversal in contrast to oral administration of hormone in fish feed.
\end{abstract}

Keywords: sex reverse, Cyprinus carpio, androgen and immersion.

\section{Masculinização na carpa comum (Cyprinuscarpio) por imersão em androgênio: Efeito da interação da concentração hormonal e do tempo de imersão}

\begin{abstract}
Resumo
Andrógenos sintéticos (hormônios masculinos) administrados ao viveiro de peixes estão sendo usados na aquicultura para evitar a diferenciação sexual e a desova indesejada nos ovos ou no primeiro estágio de alimentação dos peixes. O presente estudo foi conduzido com o objetivo de produzir carpa comum masculina (Cyprinuscarpio) pela técnica de imersão em ovos. Com essa pequena percepção, o efeito de diferentes concentrações hormonais (17 $\alpha$-metiltestosterona (a) HC: 150, 300, 450 e 600 gl-1) com tempos de imersão (IT: 24, 48 e 72 horas) e seu efeito de interação (HC x IT) na porcentagem de eclosão dos ovos de Cyprinuscarpio, a porcentagem de sobrevivência e a porcentagem da produção masculina foram avaliadas especificamente. Os resultados mostraram que a porcentagem de incubação de ovos diminuiu com o aumento da TI da mesma forma, a sobrevivência dos alevinos tratados foi afetada pelo aumento da TI $(\mathrm{P}<0,001)$. O principal efeito de interação do HC x IT mostrou que o maior percentual de indivíduos do sexo masculino (95\%) foi obtido com 450-600 $\mu \mathrm{gl}-1 \mathrm{HC}$ por 72 horas de TI, seguido por 88-92,50\% com 150-300 $\mu \mathrm{gl}-1 \mathrm{HC}$ para 72 horas de TI, $87,50 \%$ às 48 horas de TI para o restante dos tratamentos hormonais, e 47,50\% mais baixos foram registrados no controle $(\mathrm{P}<0,05)$. A porcentagem aumentada de macho de Cyprinuscarpio foi obtida com o aumento do $\mathrm{HC}$ em todas as TIs. Observou-se que o tratamento de imersão a $600 \mu \mathrm{gl}-1$ por 72 horas foi mais efetivo na alteração da razão sexual do Cyprinuscarpio antes da eclosão. Uma perspectiva comparativa feita a partir deste ensaio experimental de que a indução sexual de Cyprinuscarpio por imersão de ovos usando hormônio esteróide masculino sintético é uma técnica alternativa segura de reversão do sexo em peixes, em contraste com a administração oral de hormônio na alimentação de peixes.
\end{abstract}

Palavras-chave: sexo reverso, Cyprinuscarpio, andrógeno e imersão. 


\section{Introduction}

In order to obtain significant results in breeding and growth in aquaculture industry, it is of crucial importance to choose suitable brood stock. Now-a-days, it is a commercial activity worldwide to catch, breed and sell aquatic animals in specified water or areas. An enormous potential of common carp breeding programs can be obtained if their captive conditions are governed particularly as that of temperature effect (Razmi et al., 2011). But the problems encountered by fish farmers unavoidably at the time of fish sexual maturation includes growth suspension, degree of flesh composition and mortality rates (Aussanasuwannakul et al., 2011). Several tools and techniques has been used by fish cultivators to achieve the goals i.e. control of sexual differentiation in different ways for various fish species and to control the unwanted spawning in culturing ponds (Fernandino and Hattori, 2019), So the methods that increase the male population including manual sorting of sexes by visual examination, gene manipulation, sex reversal via steroid hormone and hybridization are under consideration (Dunham, 2011). But the need of hour is to select the appropriate method by cultivators. Manual sorting involves separation of males form females by external morphology examination of urino-genital papillae. But this method is not best suited and laborious (Kelly and Heikes, 2013). Gene manipulation is reliable but quite time demanding and labor intensive. Several broad goals in aquaculture can be reached through a better understanding of sex control (Budd et al., 2015). However the process of sex reversal administrating synthetic steroid hormone working as basic technique and is being implying frequently to promote the growth and to sex reverse fish for mono-sex male population in some species (Megbowon \& Mojekwu,2014). Testosterone is a synthetic steroid hormone which is used to produce male fish and for better growth of fish for mono sex culture in aquaculture. It is species specific because sex determination is a complicated process for which each step may vary among populations. The sex ratios can influence by many factors (Stelkens and Wedekind, 2010), but the effectiveness of hormone for sex reversal of fish depends on the type of hormone being administered during trial, its dosage, fish species, age, time and duration of treatment (Budd et al., 2015). Remarkable effects of $17 \alpha-$ methyltestosteronehave been observed. By utilizing it, the success of mono-sex male population production on this drive has been achieved through sex reversal. $17 \alpha$-methyltestosteronetreatments to fish are the most suited and reliable methods to attain sustainable fish stock (Megbowon \& Mojekwu, 2014).

Beside to advantageous effects of $17 \alpha$-methyltestosterone, it may be harmful to consumers at slighter aspect and more during granular feed formulation (Alcantar-Vazquez, 2018). Prior to research, fate and metabolites of MT need to be addressed more along with potential risks of using MT feed technology (Abo-Al-Ela, 2018). At different immersion times, $17 \alpha$-methyltestosterone has demonstrated its effects on egg hatching ability, survival rate of fry and fingerlings and sex ratio of $O$. niloticus (Junior et al., 2017).As far as way of administration is concerned, it has been well reported in literature that methyltestosterone induced through diet and fry immersion technique give stunning results to reverse the sex. Immersion of fry in sex steroids for short term of time provide good results but male population diagnosed below as that of recommended rates (Silva et al., 2013).

\section{Materials and methods}

\subsection{Brooder and Hatchling's Assembly}

Since the study was designed to determine the optimal suitable concentration of androgen $17 \alpha$-methyltestosterone hormone for sex reversal of common carp (Cyprinus carpio) through immersion method. For this purpose, mature healthy common carp brooders about (1-1.5 kg) were selected for breeding experiment from Fish Seed Hatchery Faisalabad, Pakistan. Brooders were coursed in cemented tanks of almost $(1 \mathrm{mx} 1 \mathrm{mx} 1 \mathrm{~m})$ size by ratio of ( 3 male and 2 female) facilitated with aquatic macrophytes like Hydrillaverticillata and Eichhorniacrassipes for hiding and eggs adhesion purposes (Haniffa and Sridhar, 2002). Daily checking of eggs was given out and eyed-eggs (2-3 days old) were collected from the tanks and were transferred to the laboratory aquarium for further proceedings.

\subsection{Hormonal preparation}

Stock solution of $17 \alpha$-methyltestosterone (Sigma Chemical co., USA) was formulated by dissolving the $17 \alpha$-MT in ethanol at a concentration of $1 \mathrm{mg} / \mathrm{ml}$ for egg immersion purpose which was safely maintained at dark cool place because it is photosensitive (Haniffa et al., 2004). Various hormone concentrations (HC) were prepared by adding $1.5,3,4.5$ and $6 \mathrm{ml}$ to 10 liters of water to obtain $17 \alpha$-MT concentrations of 150, 300, 450 and $600 \mathrm{ug} / \mathrm{L}$ (Piferrer and Donaldson, 1992) (Table 1).

Table 1. Eggs hatching percentage and survival of common carp (Cyprinus carpio) at different hormone concentrations and immersion times.

\begin{tabular}{cccc}
\hline $\begin{array}{c}\text { Immersion } \\
\text { time (Hrs.) }\end{array}$ & $\begin{array}{c}\text { Hormone } \\
\text { Concentration } \\
\left(\boldsymbol{\mu g l}^{-\mathbf{1}}\right)\end{array}$ & $\begin{array}{c}\text { Hatching } \\
\mathbf{( \% )}\end{array}$ & $\begin{array}{c}\text { Survival } \\
\mathbf{( \% )}\end{array}$ \\
\hline 0 & 0 & 54.50 & 75.21 \\
24 & 150 & 58.00 & 73.25 \\
& 300 & 50.00 & 69.97 \\
& 450 & 41.00 & 67.13 \\
48 & 600 & 39.00 & 65.40 \\
& 150 & 52.00 & 71.50 \\
& 300 & 46.50 & 68.08 \\
72 & 450 & 37.00 & 64.84 \\
& 600 & 37.50 & 65.40 \\
& 150 & 43.00 & 66.67 \\
& 300 & 38.50 & 59.43 \\
& 450 & 40.00 & 56.25 \\
& 600 & 35.50 & 50.52 \\
\hline
\end{tabular}




\subsection{Eggs immersion}

Succeeding the collection of eyed eggs (2-3 days old) of Cyprinus carpio from circular cemented tanks, eggs were allowed to stock in experimental capacity plastic containers of $(2.5 \mathrm{~L})$ at the density of 100 eggs per container. Eggs intended to treat were immersed in different $17 \alpha$-MT hormone concentrations (HC) of 0 (control), 150, 300, 450 and $600 \mu \mathrm{gl}^{-1}$ for varying intervals of immersion times (IT) viz., 0 (control), 24, 48 and 72 hours respectively, each with two replicates. After the designated immersion times, treated eggs were transferred to incubators for period of 4-6 days for hatching. The hatched embryos were collected at yolk sac stage via scooping then allowed to transfer to 13 indoor glass aquariums. Each glass aquaria was of 29L capacity $(90 \mathrm{~cm} \mathrm{~L} \times 30 \mathrm{~cm} \mathrm{~W} \times 45 \mathrm{~cm} \mathrm{D})$. In aquariums fish fry were fed with experimental diet (32\% crude protein) that was formulated by linear formulation method using Win feed 2.6 (Win Feed (UK) Ltd., Cambridge, UK) (Table 2). No less than $75 \%$ of water was exchanged ordinary with fresh water by guiding out water with uneaten feeds and fecal matters. The water quality parameters i.e. $\mathrm{pH}$, dissolved oxygen and temperature through YSI proseries multi parameter professional plus meter were monitored. Dissolved oxygen $(5 \mathrm{ppm})$ was maintained by air pumps through capillary system (APHA 1998).

\subsection{Gonad's squashing}

At the end of the trial five fish samples were randomly selected from each treatment and their gonad tissues were removed by fine forceps and mounted on glass slide. Few drops of acetic orcein or geimsa stain were added and the tissues were slightly squashed after placing a cover slip on the glass slide. Microscopy was done. Ovarian tissue was identified by the presence of oocytes and the testicular tissue recognized by the spermatocytes by a uniform background of tissue. Intersexes were identified by the presence of both male and female tissues in the same gonad (Guerrero and Shelton, 1974).

\subsection{Statistical analyses}

The results were statistically analyzed using Statistical Package for Social Sciences (SPSS) version 10 and general linear model. Pearson correlation analysis was used to determine the relationship of $\mathrm{HC}$, IT and hatchability. Differences in all the studied parameters were assessed by one way ANOVA.

Table 2. Percentage composition of experimental diet.

\begin{tabular}{lr}
\hline \multicolumn{1}{c}{ Ingredients \% } & Diet \\
\hline Fish meal & 19.87 \\
Rice polish & 16.14 \\
Wheat bran & 17.59 \\
Rice broken & 9.57 \\
Fish oil & 4.83 \\
Vitamin premix & 2.00 \\
Meat meal & 30.00 \\
Total: & 100.00 \\
\hline
\end{tabular}

\section{Results}

Data analysis showed that hormone concentration (HC), immersion time (IT) and their interaction of both attributes (HC x IT) has significant effects on hatching percentage, survival percentage and masculinization ratio $(\mathrm{P}<0.001)$.

\subsection{Hatched eggs percentage}

Maximum eggs hatching percentage, $58 \%$ was achieved in treatment at $150 \mathrm{\mu gl}^{-1}$ hormone concentration for duration of 24 hours immersion time while lowest value for hatching percentage was recorded $37 \%$ at immersion time $48 \mathrm{hrs}$ for the concentration $450 \mu \mathrm{gl}^{-1}$. Hatching percentages $50 \%$, $41 \%$ and $39 \%$ were recorded for 300,450 and $600 \mu \mathrm{gl}^{-1}$ hormone concentrations, respectively when immersion time provided for $24 \mathrm{hrs}$. While for immersion time of $48 \mathrm{hrs}, 52 \%, 46 \%$ and $37.50 \%$ and $37 \%$ eggs hatching percentage were recorded at 150, 300, 450 and $600 \mu^{-1}$ hormonal concentrations, respectively. For immersion time of $72 \mathrm{hrs}, 43 \%, 40 \%, 38.50 \%$ and $35.5 \%$ hatching percentage were recorded at hormone concentrations 150, 450, 300 and $600 \mu \mathrm{gl}^{-1}$, respectively (Table 1).

\subsection{Index of survival percentage inside aquarium}

The use of $17 \alpha$-methyltestosterone with various immersion times showed remarkable effect on sex ratios and survival percentages depicting that there is positive and constant relation between hormonal concentration, survival percentage index, immersion time and resultant fish population. Results revealed that the control group at the hormonal concentration of $0 \mu \mathrm{gl} \mathrm{l}^{-}$ showed the highest post-treatment survival percentage (75.21\%) followed by $(73.25 \%$ ) survival rate across the HC (hormonal concentration) of $150 \mu \mathrm{gl}^{-1}$ with IT (immersion time) of $24 \mathrm{hrs}$ while the lowest survival rate $(50.52 \%)$ was recorded for IT of $72 \mathrm{hrs}$ across the $\mathrm{HC}$ of $600 \mu \mathrm{gl}^{-1}$. For immersion time of $24 \mathrm{hrs}$, the survival rates for Cyprinus carpio were 69.97\%, $67.13 \%$ and $65.40 \%$ across the hormonal concentrations of 300,450 and $600 \mu \mathrm{gl}^{-1}$, respectively. For immersion time of $48 \mathrm{hrs}$ the survival percentages recorded for Cyprinus carpio were $71.50 \%, 68.08 \%, 65.40 \%$ and 64.84 at $\mathrm{HCs}$ $150,300,600$ and $450 \mu \mathrm{gl}^{-1}$, respectively. While for immersion time of 72 hours the survival rates were $66.67 \%, 59.43 \%$, $56.25 \%$ and $50.52 \%$ at $\mathrm{HC} 150,300,450$ and $600 \mu \mathrm{gl}^{-1}$, respectively (Table 1).

\subsection{Effect of $17 \alpha$-methyltestosterone on Histological indices}

Histological study of common carp (Cyprinus carpio) gonads at 120 days old stage was observed in oocytes and spermatogonia. Histological examination of fish gonads showed that female gonads had oocytes whereas male gonads composed of spermatogonia. Spermatogonia were in aggregated form while those of oocytes in female gonads can be visualized as small spherical cells that can be distinguished easily because of their larger nucleus to cytoplasmic ratios (Figure 1a and $1 \mathrm{~b}$ ). As the newly hatched fry were treated with $17 \alpha$-methyltestosterone inside the treatment containers, the undifferentiated gonadal tissues of female population begin towards the development of testicular tissues. Briefly, this study provided a positive 


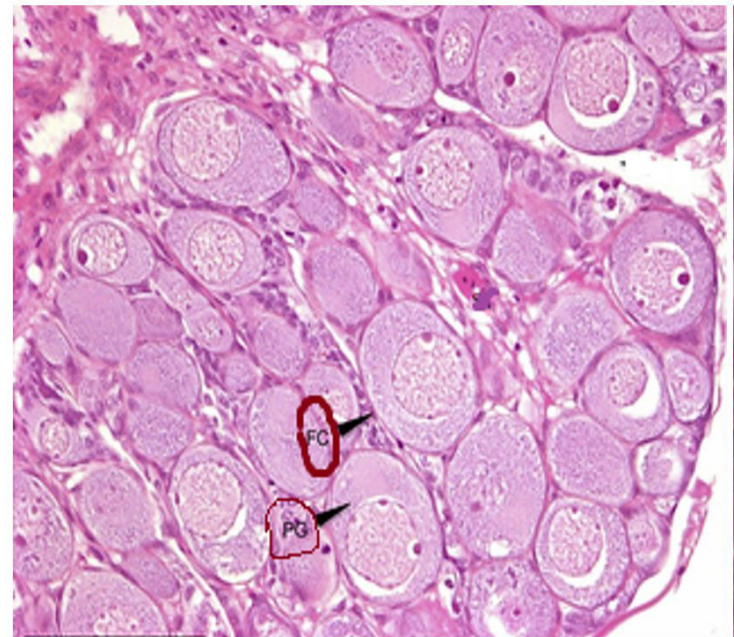

Fig.1(a) Female gonad

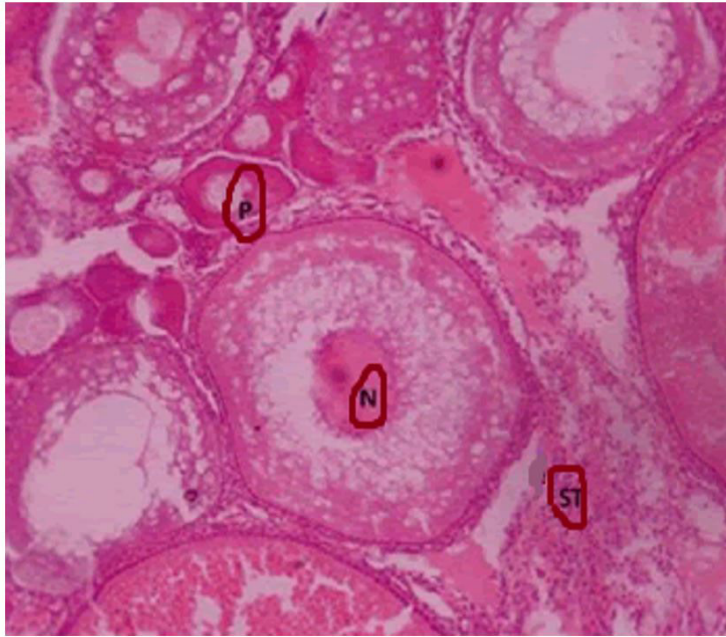

Fig.1.(b) Male gonad

Figure 1. (a)Female gonad of Cyprinus carpio at IT $300 \mu \mathrm{gl}^{-1}$ and $\mathrm{HC} / 24 \mathrm{hr}$ showing primary growth of oocyte (PG) and follicular cell (FC). Whereas Figure 1 (b)Male gonad of Cyprinus carpio at IT $600 \mu \mathrm{gl}^{-1}$ and HC/72hr showing big nucleus (N), spermatids (ST) and perinuclear cells.
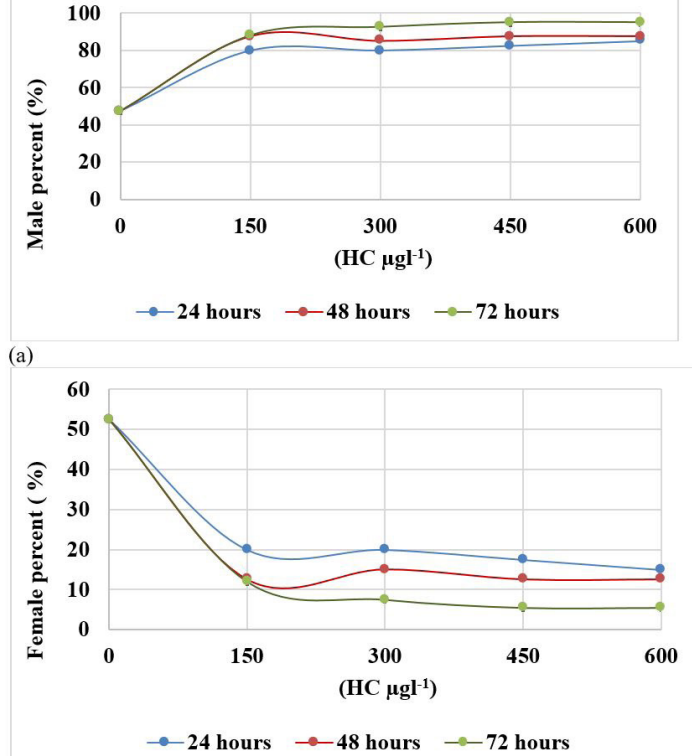

(b)

Figure 2. (a) Percentage of male population of Cyprinus carpio under control and different treatments (HC x IT). (b) Percentage of female population of Cyprinus carpio under control and different treatments (HC x IT).

correlation among significant concentration of hormone and their rate of sex reversal. Along with this, immersion time period also showed pronounced effect on male population as significant variations were observed.

\subsection{Comparative evaluation of Sex expression}

Significantly highest percentage of male population was recorded (95\%) for IT $72 \mathrm{hrs}$ at HCs 450 and $600 \mu \mathrm{gl}$ - followed by $87.50 \%$ and $85.0 \%$ for corresponding ITs of $48 \mathrm{hrs}$ and
$24 \mathrm{hrs}$ under the influential HCs of 150, 300 and $600 \mu \mathrm{gl}^{-1}$ respectively. While in female population, higher percentage $52.5 \%$ was recorded for control group while a decreasing trend in female populations as $20 \%, 17.5 \%$ and $15.0 \%$ was recorded with $\mathrm{HCs}$ of $150,300,450$ and $600 \mu \mathrm{gl}^{-1}$ at ITs of 24,48 , and $72 \mathrm{hrs}$, respectively. Results of this study revealed that there is highly significant effect of $\mathrm{HC} \times$ IT interaction on sex reversibility $(\mathrm{P}<0.01)$ (Figure $2 \mathrm{a}$ and $2 \mathrm{~b}$ ).

\section{Discussion}

This study sought to determine the optimum hormonal concentration of $17 \alpha$-methyltestosterone and immersion time to obtained maximum sex reversal of common carp. The results showed significant effect on sex reversal and survival of common carp (Cyprinus carpio). From results finding it was concluded that use of androgen hormone by immersion technique is most efficient and least expensive method in fish sex reversal.

\subsection{Hatching percentage and survival}

Stunning results supporting significant influence of hormone concentration (HC), immersion time (IT) and their interaction $(\mathrm{HC} \times \mathrm{IT})$ on hatching percentage and sex reversal of common carp have been discussed. An appropriate concentration of $17 \alpha$-methyltestosterone which is influential in increasing survival percentage and hatching percent of common carps was found through this research. These concentrations may still be suitable because eggs were used instead of fry. Similar convincing results for efficacy of this hormone were obtained by (Rima et al., 2017). Maximum rate of survival (75.21\%) was observed in controlled group than hormone treated group. Highest hormone concentrations affect the hatching percentage and survival as reported by Jensi et al. (2016) in their findings. It was perceived during experimental trial that 
longer the immersion time, more survival threats would be there for hatchlings. Hence, greater chances of survival are expected with control group while group of fingerlings confronting the hormones (either through feeding or via immersion time), however drive an opposed conclusion as Khanal et al.(2014) reported.

\subsection{Sex reversal percent}

From examination of the histological aspects of gonadal tissues of Cyprinus carpio, it was revealed that in domain of sex reversal and mono sex male population $17 \alpha$-methyltestosterone had considerable effects. By utilizing egg immersion technique, commercially beneficial results in various fish species have been obtained. Groups confronting the hormones (through immersion times) produced pronounced gain in maleness percent as found in work of Khanal et al. (2014).

Supreme ratio of mono sex male population of common carp was recorded in each hormone treated group as compared to control group. These results envisaged that each hormone treated group gave a mean male/female ratio which deviate significantly from the normal 1:1 ratio. Similar convincing results were found by Kumar and Haniffa (2011) who obtained high ratio of male at high androgen hormone concentration. Control of sex differentiation through the hormones immerson is generally achieved through the exposure of sexually undifferentiated fish to an appropriate level of exogenous sex steroids.

Our research suggested that reason behind increment of male sex percent was exposed through histological examinations. Endocrine chemicals have detrimental effects on gonadal structure of fish population but some contradictory statements were reported by Senior et al. (2012), that chemicals used for induced sex reversal they don't have had any severe effect on survival. In addition they showed some impairing impacts on gonadal structures. An increased in yield of male population was ensured successfully by utilizing higher $\mathrm{HC}$ with longer IT while none of the hormonal concentration has proved remarkable in increasing female population percent. However, induction of immersion technique has made the sex reversal possible by immersing the Cyprinus carpio eggs in $17 \alpha$-methyltestosterone rather than other traditional techniques. It was perceived through results that there is an inverse relation between immersion time and survival ratio of fish population. Where the sex graph of Cyprinus carpio was leading ahead the production of male population by using $17 \alpha$-methyltestosterone, its immersion time duration was affecting the survival ratios as well.

\section{Conclusion}

Production of mono-sex male population of Cyprinus carpio by using $17 \alpha$-methyltestosterone is an effective technique. From the study it was concluded that induction of sex reversal can be achieved by hormone egg immersion technique. Through this a little insight, précised concentrations of hormone have been suggested to get a good performance in sex reversal methods. However, immersion period and concentrations of androgen $17 \alpha$-methyltestosterone demonstrated positive effects in obtaining mono-sex male population and not sure that any adverse effect of hormone has been examined rather than affecting survival rate. Further work is expected to perform in domain of methods used for sex reversal.

\section{References}

ABO-AL-ELA, H.G., 2018. Hormones and fish monosex farming: A spotlight on immunity. Fish \& Shellfish Immunology, vol. 72, pp. 23-30. http://dx.doi.org/10.1016/j.fsi.2017.10.038. PMid:29079204.

ALCÁNTAR-VÁZQUEZ, J.P., 2018. Sex proportion in Nile tilapia (Oreochromis niloticus) fed estrogen mixtures: A case of paradoxical masculinization. Latin American Journal of Aquatic Research, vol. 46, no. 2, pp. 337-345. http://dx.doi.org/10.3856/ vol46-issue2-fulltext-9.

AMERICAN PUBLIC HEALTH ASSOCIATION - APHA. 1998. Standard methods for the examination of water and wastewater. 20th ed. Washington, DC: APHA, pp. 205-290.

AUSSANASUWANNAKUL, A., KENNEY, P.B., WEBER, G.M., YAO, J., SLIDER, S.D., MANOR, M.L. and SALEM, M., 2011. Effect of sexual maturation on growth, fillet composition, and texture of female rainbow trout (Oncorhynchus mykiss) on a high nutritional plane. Aquaculture (Amsterdam, Netherlands), vol. 317, no. 1-4, pp. 79-88. http://dx.doi.org/10.1016/j.aquaculture.2011.04.015.

BUDD, A.M., BANH, Q.Q., DOMINGOS, J.A. and JERRY, D.R., 2015. Sex control in fish: Approaches, challenges and opportunities for aquaculture. Journal of Marine Science and Engineering, vol. 3, no. 2, pp. 329-355. http://dx.doi.org/10.3390/jmse3020329.

DUNHAM, R.A.2011. Aquaculture and fisheries biotechnology and genetics. Oxfordshire: CABI - Nature, $495 \mathrm{p}$.

FERNANDINO, J.I. and HATTORI, R.S., 2019. Sex determination in Neo tropical fish: Implications ranging from aquaculture technology to ecological assessment. General and Comparative Endocrinology, vol. 273, pp. 172-183. http://dx.doi.org/10.1016/j. ygcen.2018.07.002. PMid:29990492.

GUERRERO, R.D.3rd. and SHELTON, W.L., 1974. An acetocarmine squash method for sexing juvenile fishes. Progressive FishCulturist, vol. 36, no. 1, pp. 56-56. http://dx.doi.org/10.1577/15488659(1974)36[56:AASMFS]2.0.CO;2.

HANIFFA, M.A., SRIDHAR, S. and NAGARAJAN, M., 2004. Hormonal manipulation of sex in stinging catfish Heteropneustesfossilis (Bloch). Current Science-Bangalore, vol. 86, no. 7, pp. 1012-1016.

HANIFFA, M. A.K. and SRIDHAR, S., 2002. Induced spawning of spotted murrel (Channapunctatus) and catfish (Heteropneustesfossilis) using human chorionic gonadotropin and synthetic hormone (ovaprim). Veterinarskirhiv, vol. 72, no. 1, pp. 51-56.

JENSI, A., MARX, K.K., RAJKUMAR, M., SHAKILA, R.J. and CHIDAMBARAM, P., 2016. Effect of $17 \alpha$-methyl testosterone on sex reversal and growth of Nile tilapia (Oreochromis niloticus L., 1758). Ecology Environment and Conservation, vol. 22, no. 3, pp. 1493-1498.

JUNIOR, M.Z., NAUFAL, M.R., SETIAWATI, M., HARDIANTO, D. and ALIMUDDIN., 2017. The sex ratio and testosterone levels in tilapia immersed in different doses of $17 \alpha$-methyltestosterone. Journal Akuakultur Indonesia, vol. 16, no. 1, pp. 51-59. http:// dx.doi.org/10.19027/jai.16.1.51-59. 
KHANAL, N.B., SHRESTHA, M.K., RAI, S. and BHUJEL, R.C., 2014. Comparative evaluation of Carp testis as an alternative to $17 \alpha$-Methyltestosterone on Tilapia sex reversal. Our Nature, vol. 12, no. 1, pp. 1-7. http://dx.doi.org/10.3126/on.v12i1.12251.

KELLY, A.M. and HEIKES, D.2013. Sorting and grading warm water fish. Stoneville, Mississippi: Southern Regional Aquaculture Center.

KUMAR, A. and HANIFFA, M.A.K., 2011. Effect of $17 \alpha-$ Methyltestosterone on Sex Reversal of Xiphophorus maculatus Platy and Cyprinus carpio Koi carp.Journal of Research in Biology, vol. 11, no. 8, pp. 580-586.

MEGBOWON, I. and MOJEKWU, T.O., 2014. Tilapia sex reversal using methyl testosterone (MT) and its effect on fish, man and environment. Biotechnology (Faisalabad), vol. 13, no. 5, pp. 213-216. http://dx.doi.org/10.3923/biotech.2014.213.216.

PIFERRER, F. and DONALDSON, E.M., 1992. The comparative effectiveness of the natural and a synthetic estrogen for the direct feminization of chinook salmon (Oncorhynchus tshawytscha). Aquaculture (Amsterdam, Netherlands), vol. 106, no. 2, pp. 183193. http://dx.doi.org/10.1016/0044-8486(92)90202-V.

RIMA, N.N., MUHAMMAD, M.R. and MUHAMMAD, J.S., 2017. Optimization of $17 \alpha$-methyl testosterone hormone dose during masculinization of Nile tilapia (Oreochromis niloticus) fry. Journal of Noakhali Science and Technology University, vol. 1, no. 2, pp. 35-41.

RAZMI, K., NAJI, T., ALIZADEH, M. and HOSEINZADEH SAHAFI, H., 2011. Hormonal sex reversal of rainbow trout (Oncorhynchus mykiss) by ethynylestradiol-17 $\alpha$ (EE2). Iranian Journal of Fisheries Science, vol. 10, no. 2, pp. 304-315.

SENIOR, A.M., LIM, J.N. and NAKAGAWA, S., 2012. The fitness consequences of environmental sex reversal in fish: a quantitative review. Biological Reviews of the Cambridge Philosophical Society, vol. 87, no. 4, pp. 900-911. http://dx.doi. org/10.1111/j.1469-185X.2012.00230.x. PMid:22540898.

STELKENS, R.B. and WEDEKIND, C., 2010. Environmental sex reversal, Trojan sex genes, and sex ratio adjustment: conditions and population consequences. Molecular Ecology, vol. 19, no. 4, pp. 627-646. http://dx.doi.org/10.1111/j.1365-294X.2010.04526.x. PMid:20088884.

SILVA, F.C., ZARAZÚA, S.M.G., PACHECO, T.I. and RANGEL, F.A., 2013. Male tilapia production techniques, mini review. African Journal of Biotechnology, vol. 12, no. 36, pp. 5496-5502. 